\title{
Intracranial Mesenchymal Chondrosarcoma: A Case Report
}

\section{İntrakranial Mezenkimal Kondrosarkom: Bir Olgu Sunumu}

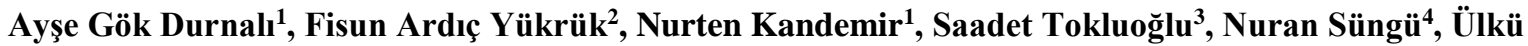 \\ Yalçıntaş Arslan', Kaan Helvacı' ${ }^{1}$, Necati Alkış ${ }^{1}$ \\ ${ }^{1}$ Department Of Medical Oncology, Dr A. Y. Ankara Oncology Training And Research Hospital, \\ Ankara, Turkey \\ ${ }^{2}$ Department Of Pathology, Dr A. Y. Ankara Oncology Training And Research Hospital, Ankara, Turkey \\ ${ }^{3}$ Department Of Medical Oncology, Güven Hospital, Ankara, Turkey \\ ${ }^{4}$ Department Of Pathology, Atatürk Training And Research Hospital, Ankara, Turkey
}

Dergiye Ulaşma Tarihi:27.02.2015 Dergiye Kabul Tarihi:14.07.2015 DOI: 10.5505/aot.2016.26349

\section{ÖZET:}

İntrakranial Kondrosarkomlar çok nadir görülen malign tümörlerdir, intrakranial tümörlerin sadece \%15'ini oluştururlar. $\mathrm{Bu}$ tümörlerin tedavisinde, cerrahi rezeksiyon ve adjuvan radyoterapi temel yaklaşımlardır. Kemoterapinin rolü iyi tanımlanmamıştır. Biz burada intrakranial mezenkimal kondrosarkom tanılı 26 yaşında erkek hastayı sunduk.

Anahtar Kelimeler: İntrakranial, Kemoterapi, Mezenkimal kondrosarkom, Tedavi

\section{ABSTRACT:}

Intracranial chondrosarcomas are very rare malignant tumors, account for only $0.15 \%$ of all intracranial tumors. Surgical resection and adjuvant radiotherapy are main approaches of treatment in the treatment of these tumors. The role of chemotherapy is not well defined. We presented a 26 year-old- man diagnosed with intracranial mesenchymal chondrosarcoma.

Keywords: Chemotherapy, Intracranial, Mesenchymal chondrosarcoma, Treatment

\section{Introduction}

Chondrosarcoma is a rare malignant tumor that originates from cartilaginous tissue. It is mostly located in long bones and pelvic region, only $7 \%$ of chondrosarcomas grow in the craniocervical region and it accounts only $0.15 \%$ of all intracranial tumors $(1,2,3)$. Microscopically tumor displays a dimorphic pattern characterized by well differentiated cartilage with abrupt boundary from undifferentiated stroma composed of small/round oval cells resembling lymphoma, hemangiopericytoma or Ewing's sarcoma/ Primitive neuroectodermal tumor (PNET). Differential diagnosis includes small blue round cell tumors, small cell osteosarcoma. Surgical resection and irradiation is mainstay of treatment (4). Because of the rarity of intracranial chondrosarcomas, the role of chemotherapy is not well defined.

Herein we reported our intracranial mesenchymal chondrosarcoma patient and treatment outcomes.

\section{Case Report}

A 26 year-old- man was admitted to hospital in with the history of progressive headache and sudden loss of consciousness. Cranial imaging showed intracranial mass in right temporoparietal region. He underwent surgical excision of this intracranial mass and pathological evaluation of excision material reported as mesenchymal chondrosarcoma, grade 4, according to WHO 2000. Microscopically tumor displayed a dimorphic pattern characterized by well differentiated cartilage with abrupt boundary from undifferentiated stroma composed of small/round oval cells (Figures 1, 2, 3, 4)

Immunohistochemically there was no staining with S100 (S100 positivity only in chondroid areas), desmin, actin, cytokeratin, EMA and synaptohysin.

A local recurrence was detected during postoperative 4th month, and the patient received radiation therapy at a dose of $60 \mathrm{~Gy}$ 
with the response of partial regression. Approximately 3 years later, there was progressive mass in the same region and surgical excision followed by stereotactic radiation therapy was performed. Two months later, the patient underwent third surgical excision procedure for rapid local recurrence, but total excision was impossible due to multiplicity of lesions. After this last operation, no additional radiation therapy was planned and he was admitted to our department to be evaluated for chemotherapy. On imaging studies performed at that time, there was no distant metastasis and cranial magnetic resonance imaging showed recurrent mass lesions on occipital lobe and partial herniation of brain parenchyma from craniotomy line (Figure 5).

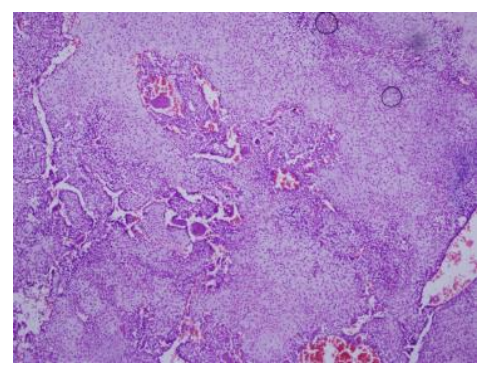

Figure 1. Islands of cartilage admixed with undifferentiated small ovoid cells HEx40

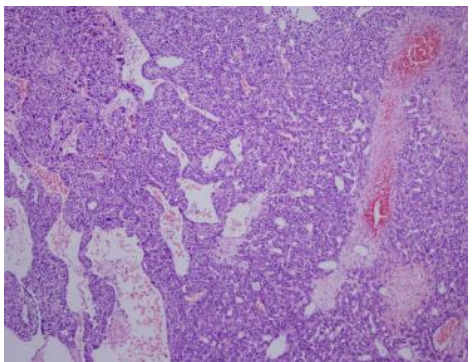

Figure 3. Undifferentiated round cell tumor with a typical hemangiopericytomatous vascular pattern HEX40

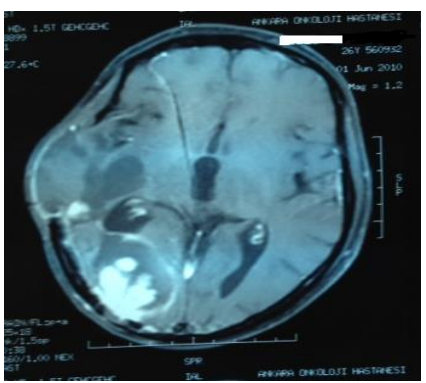

Figure 5. Cranial magnetic resonance imaging showed recurrent mass lesions on occipital lobe and partial herniation of brain parenchyma from craniotomy line
As doxorubicin is essential drug for the treatment of most types of sarcomas and also mesenchymal chondrosarcomas of bone and soft tissue (5), doxorubicin and ifosfamide with mesna protection was started. After 3 weeks of 4th cycle of this chemotherapy regimen, progressive disease was detected. Second line 4 cycles of cisplatin based chemotherapy regimen (cisplatin and doxorubicin was given with the response of stable disease. After 2 months of last chemotherapy cycle, there was progressive disease and the patient died 1 month later. Survival time of our patient from the beginning of chemotherapy cycles was 9 months and from first operation was 51 months.

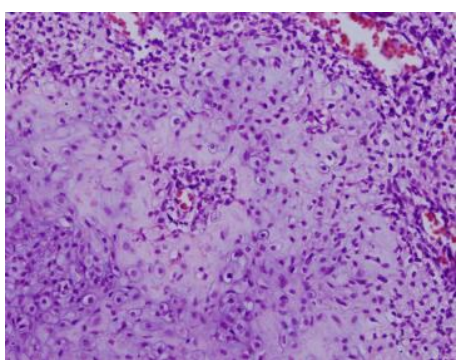

Figure 2. Low grade cartilaginous areas HEX200

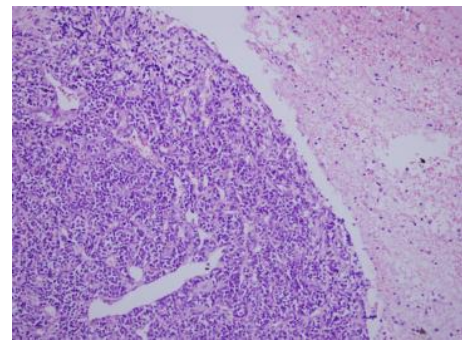

Figure 4. Undifferentiated small round cell tumor adjacent to brain tissue 


\section{Discussion}

Chondroid tumors infrequently originate from extra skeletal regions. Intracranial chondrosarcomas constitute only $0.15 \%$ of all intracranial tumors (3). There are different theories for the development of intracranial chondrosarcoma. Some reports have postulated that they might develop from chondrocytes in rests of endochondral cartilage, others have suggested that they might be arising from primitive multifunctional mesenchymal cells in embryogenesis of skull base or temporal bone or from metaplastic mature fibroblasts of from undifferentiated cells from cartilaginous synchondroses $(1,2,6)$. Histopathologically they are subclassified into conventional, dedifferentiated, clear cell and mesenchymal types (1). Conventional subtype is most common type, usually locates at the base of skull $(6,7)$. Mesenchymal subtype is more anaplastic type, may spread to distant sites (1). Prognosis is determined mainly by its WHO histological grade (1).

Intracranial chondrosarcomas sometimes mimics meningiomas, present with symptoms of mass effect such as increased intracranial pressure, nerve palsies, seizures $(1,8)$. CT scans show iso-hyperdense lesion, variable degrees of heterogeneous enhancement and varying amounts of calcification (7). MR imagines show better demarcation and the pattern of heterogeneous enhancement which is typical for this malignancy $(7,9)$. On pathological examination, S100 and vimentin positive, epithelial markers such as EMA and cytokeratin are negative (2).

Surgical resection is the mainstay in treatment of cranial chondroid tumors $(1,4,7)$ and postoperative adjuvant radiation may reduce mortality $(1,4,7,10)$. But for low grade chondrosarcomas, to determine the role of adjuvant therapy, investigations must be performed (1).

In a review, 5-year mortality rate was found to be $26 \%$ for patients treated with only surgery, addition of postoperative radiation therapy reduced this rate to $4 \%$ (1). In the same study, 5 -year mortality rates were $6 \%$ and $54 \%$ in patients with conventional and mesenchymal chondrosarcomas respectively, overall 5-year mortality was $11 \%$; median survival was 24 months (1).
The data about the role of chemotherapy for treatment of intracranial chondrosarcomas is very limited. Rapidis et al. also reported that chemotherapy was not effective (11). La spina et al suggested that adjuvant chemotherapy, a "sarcoma-like" course of chemotherapy: CEV, IVE, CEV, CAV-HDx3 (carboplatin, etoposide, vincristine, ifosfamide, and adriamycin), might have a role in the local control of intracranial mesenchymal chondrosarcoma, especially when total surgery was not possible (12). Aksoy et al, reported that a 31 -year-old patient with recurrent intracranial mesenchymal chondrosarcoma who had no further surgery or radiation therapy options, achieved a good clinical response with temozolomide (13). In a systematic review of 107 patients with mesenchymal chondrosarcoma of bone and soft tissue, it was reported that highly variable regimes were used as adjuvant treatment, including dactinomycin, carboplatin, cisplatin, cyclophosphamide, doxorubicin, etoposide, ifosfamide, high-dose methotrexate, and vincristine; and there was no general agreement on the regimen of chemotherapy as the adjuvant therapy of mesenchymal chondrosarcoma, except for doxorubicin as a cornerstone (5).

With these limited literature data and outcomes of our patient, prognosis of intracranial chondrosarcoma depends mostly on grade, histopathological subtype, and treatment type (surgical excision is mandatory, adjuvant radiation therapy for complete or incompletely resected tumor is likely to be beneficial). The role of chemotherapy at adjuvant or metastatic settings may be important for high grade intracranial chondrosarcomas, especially mesenchymal subtype. For patients with recurrent tumor and with no further surgery or radiotherapy options, studies for effective chemotherapy regimens are required.

\section{Conflict of interest: None}

\section{References}

1. Bloch OG, Jian BJ, Yang I, et al. A systematic review of intracranial chondrosarcoma and survival. J Clin Neurosci. 2009;16: 1547-51

2. Oruckaptan HH, Berker M, Soylemezoglu F, Ozcan OE. Parafalcine chondrosarcoma: an unusual localization for a classical variant. Case report and review of the literature. Surg Neurol. 2001; 55: 174-9 
3. Cianfriglia F, Pompili A, Occhipinti E. Intracranial malignant cartilaginous tumours. Report of two cases and review of literature. Acta Neurochir (Wien). 1978; 45: 163-75

4. Cherekaev VA, Golbin DA, Gasparyan TG, Shishkina LV, Tsukanova TV. Management of craniofacial chondroid tumors. J Craniofac Surg. 2015; 26: 10-8

5. Xu J, Li D, Xie L, Tang S, Guo W. Mesenchymal Chondrosarcoma of Bone and Soft Tissue: A Systematic Review of 107 Patients in the Past 20 Years. PLoS One. 2015; 10: e0122216

6. Chandler JP, Yashar P, Laskin WB, Russell EJ. Intracranial chondrosarcoma: a case report and review of the literature. J Neurooncol. Review. 2004; 68: $33-9$

7. Güneş M, Günaldi $O$, Tuğcu B, Tanriverdi $O$, Güler AK, Cöllüoğlu B. Intracranial chondrosarcoma: a case report and review of the literature. Minim Invasive Neurosurg. 2009; 52: 238-41

8. Boccardo M, Bavaresco E, Sola S, Vitali A. Parafalcine chondrosarcoma: report of a case and review of the literature. J Neurosurg Sci. 2009; 53: $137-40$

9. Kothary N, Law M, Cha S, Zagzag D. Conventional and perfusion MR imaging of parafalcine chondrosarcoma. AJNR Am J Neuroradiol. 2003; 24: 245-8

10. Kan Z, Li H, Zhang J, You C. Intracranial mesenchymal chondrosarcoma: case report and literature review. Br J Neurosurg. 2012; 26: 912-4.

11. Rapidis AD, Archondakis G, Anteriotis D, Skouteris CA. Chondrosarcomas of the skull base: review of the literature and report of two cases. J Craniomaxillofac Surg. 1997; 25: 322-7.

12. La Spina M, Dollo C, Giangaspero F, Bertolini P, Russo G. Intracranial mesenchymal chondrosarcoma with osteoid formation: report of a pediatric case. Childs Nerv Syst. 2003; 19: 680-2

13. Aksoy S, Abali H, Kiliçkap S, Güler N. Successful treatment of a chemoresistant tumor with temozolomide in an adult patient: report of a recurrent intracranial mesenchymal chondrosarcoma. J Neurooncol. 2005; 71: 333-4 